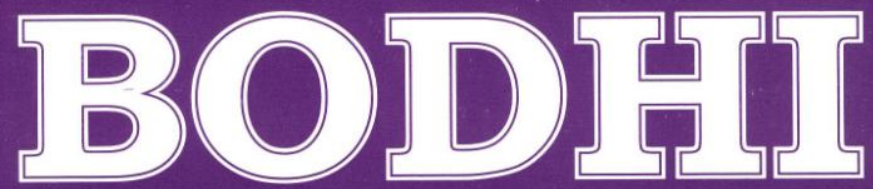

An Interdisciplinary Journal

ISSN: 2091-0479

Department of Languages and Mass Communication School of Arts

Kathmandu University

Bodhi, 4 (1), 198-209. ISSN 2091-0479. (C) 2010 Kathmandu University 


\section{Global audiences, local images: The question of exoticization in Slumdog Millionaire}

-Tika Lamsal

In this essay, I examine Slumdog Millionaire (SM) in relation to some of the tensions underlying the movie due to incongruent cultural assumptions between the Western production crew and the local socio-cultural values in the Indian subcontinent. The treatment of local cultural images in the movie offers a conflictual spectacle, leaving a cultural gap between the local and the global audiences. I analyze the tensions by reading narrative as well as images used in the movie to show how the film plays on particular cultural images/themes to appeal to Western audiences through the exoticization of local cultural images. I argue that the movie speaks more to the Western than to the local audiences. My hunch is that by reinforcing the theme of individuality and success, and by invoking local images and stereotypes, the British film director, Danny Boyle, offers a romantic spectacle of slum lives and other local practices in India for Western viewership.

\section{Global versus local: The presence of America in the movie}

The film's plot is structured around one of the popular Indian reality shows Kaun Banega Croprpati? (Who Wants to Be a Millionaire?). From the way the director selects and structures the film in terms of narrative, images, and photography shows that the movie revolves around Western themes in a way to make it more pleasing to Western audiences than to local audiences in the Indian subcontinent. Kaun Banega Croprpati? is similar to an American TV show Who Wants to Be a Millionaire? that covers a large viewership both in and outside the US. However, the way the audiences in the West and that in South Asia read the connotation of this program and assume their position in relation to the show may differ as per their own cultural perspectives to the show. It is because Kaun Banega 
Crorepati? has earned a popular culture status in South Asia as a show that has given rise to popular phrases in people's lives like lock kardun? tala lagadijayen? (should I lock it?) etc., and also to a significant number of daily shows and parodies, which become deeply rooted in the day-to-day South Asian cultural repertoires. Since its inception in 2000, Kaun Banega Crorepati? has become a popular culture icon among the local viewers with its parodies like Kaun Banega Champu? televised in India with wider viewership.

In the meantime, the production of Kaun Banega Crorepati? has a different significance among the local audiences as a talisman to recover the financial situation of its founder host Amitabh Bachchan. Unlike the mass appeal of this show in South Asia, Who Wants to Be a Millionaire? has an appeal to American dream in terms of its "rags-to-riches" story. By using a narrative that reinforces rags-to-riches growth of its protagonist, $S M$ makes the presentation more focused on Western audiences. Most of the Western viewers who are familiar with this show cherish a dream of winning the contest, and readily project their image upon the character in the hot seat, with a belief that even a participant from a materially nonprivileged community is equally likely to win the contest. Such belief may have been affected by the Western belief in rags-toriches growth of an individual, especially rooted in the American dream.

When we observe the structure of $S M$, we notice that Western culture, especially American, haunts it and prevails as a popular culture leitmotif throughout the movie. The movie thus is caught in the exhibits and spectacles that demand a wider viewership in the West. The exhibits to the West, such as the success story of the poverty-stricken Jamal, however, become the dreams within India, where many slum children like Jamal are in a quest for the America of success and desire that is deeply embedded in their local imaginary. For example, Jamal's dream in the movie to participate in the contest Who Wants to Be a Millionaire? and win it is also a dream of an individual to 
succeed in a hostile world. While Jamal's struggle to escape the slum offers a romantic spectacle of individual mobility to the Western audiences, leading to the base camp of American dream, the same struggle becomes a part of day-to-day living to the South Asian audiences. Before he is able to make it out for his participation in the show, Jamal has to undertake a series of hardships. His stealing bread from the lunching travelers in the train, selling pictures in the streets and guiding the tourists in Taj Mahal are among daily experiences of such hardships that the local audiences are well familiar with. In the meantime, these scenes also prepare global audiences to believe that everyone is entitled to success in the globalized world if he/she works hard as Jamal does. The slum hero succeeds on account of his own individual efforts to be able to participate in Who Wants to Be a Millionaire? and win the contest finally. His keen desire for information in the globalized world, however, is equally instrumental in leading Jamal to the red carpet of success. While such scenes offer intimate relationships between movie characters and local audiences, they serve as "interesting" local materials for the gaze of Western audiences.

In The Rhetoric of Empire Spurr (1993) talks about the overpowering and potentially destructive effect of postcolonial gaze. Spurr argues that the gaze is an "active instrument of construction, order, and arrangement," that functions in the form of a commanding view, which "offers aesthetic pleasure on one hand, information and authority on the other" (p. 15). Spurr's idea here helps us see the images, such as the riots between Hindus and Muslims in which Jamal's mother is killed, the projection of the corrupt police officers and the host of the TV show, the role of the underworld villains in shaping the lives of Salim and Latika, represented in the movie as third world stereotypes, which have wider appeals to the Western audiences. These images foreground a negative as well as exotic picture of the third world metropolis like Mumbai. Despite their miserable situations, the cities like Mumbai still offer an optimism for a larger populace, which is absent in the movie because it epitomizes the success of a slum hero only in 
the form of a dream achievement rather than a possibility in the lives of slum dwellers. Prakash (2005) captures such hope that the cities like Mumbai can offer: "Whatever else cities may be, they almost always represent an aspiration, a desire for a better future" (p. 138). However, what is lacking in the movie is such a desire for a better future.

Boyle's postcolonial gaze thus results in the most readily available representation of the "other." Such gaze offers the British director both aesthetic pleasure and information and assumed authority about the local people and their cultures. The irony of such gaze is that many talented Bollywood film directors and producers with a vast knowledge about the local people and cultures as well as their harsh realities hardly get their movies acclaimed in the international market. In the words of Sohat \& Stam (1996), "While the Third World is inundated with North American films, TV series, popular music, and news programs, the First World receives precious little of the vast cultural production of the Third World, and what it does receive is usually mediated by transnational corporations" (p. 148). SM is one of such precious little of the cultural production of India that is mediated by the Western production company and popularized in the West. So what is mediated becomes presentable to the Western audiences while it escapes the reality. Amitabh Bachchan (2009), the cultural icon of Hindi cinema, points out that the mediated picture of the hardships of Indian life gets an international accolade to $S M$. He regrets that $S M$ has to succeed by presenting an underbelly of a developing nation:

If $S M$ projects India as Third World dirty under belly developing nation and causes pain and disgust among nationalists and patriots, let it be known that a murky under belly exists and thrives even in the most developed nations. Its just that the SM idea authored by an Indian and conceived and cinematically put together by a Westerner, gets creative Globe recognition. The other would perhaps not. The commercial escapist world of Indian Cinema had vociferously battled for 
years, on the attention paid and the adulation given to the legendary Satyajit Ray at all the prestigious Film Festivals of the West, and not a word of appreciation for the entertaining mass oriented box office block busters that were being churned out from Mumbai. The argument. Ray portrayed reality. The other escapism, fantasy and incredulous posturing. Unimpressive for Cannes and Berlin and Venice. (par. 3)

Bachchan's indication is towards the nexus between power and circulation, for he clearly implies that the same kind of local images about poverty and people's sufferings, picked up by some other Indian producers or directors, could not grasp any attention of the Western media and audiences. It is the status of the production crew that determines the fate of a text like $S M$. The involvement of a famous Western director, and a producer, proves to be a Midas touch to bring the slum life of Mumbai people to the notice of the whole world, leading to SM's blockbuster hit in the Hollywood, winning it Academy Awards in eight different genres.

Even the protagonists in the movie are Anglo-Indians recruited to represent Mumbaish flair in the movie. That they have been successful to rise as popular stars in the eyes of their Indian audiences has to do with their Indian appearance. Their real-life social practices seem in sharp contrast with their movie-life social practices. The former has more appeal to cater to the viewership of Western audiences because they see in the stars' success their own reflection of success and in the stars' standard Westernized language and mannerisms their own language and mannerisms. They internalize the fact that the protagonists are Western born and resemble them culturally and linguistically despite their Indian outlook. The director plays upon the AngloIndian identity of Dev and Frieda in order to represent them in the images of the Western audiences culturally and that of Indian audiences biologically. So the movie's connection to the Indian audiences is created mostly through the protagonists' physical likeness with them, which, for the time being, can give 
them an impression that Jamal and Latika's success in the movie marks the possibility of a similar achievement in their own life. On the other hand, the movie can have even larger appeal among Western audiences by capturing events in the lives of the characters that are familiar to them.

Another important strategy Boyle uses to make this movie a better choice for Western audiences is the use of English language. Despite the whole movie's setting in the local places and use of local images of poverty and other complexities of local people's lives in India, hardly ten percent of the language spoken by the characters is local. The English language in the movie functions not only as a medium of better communication among the Western audiences but also as an instrument to hold out a mediated knowledge about the local identities and cultures of the source people to the target audiences. The selection of English to talk about the harsh realities of the slum dwellers in Mumbai itself makes the local participation nil because it keeps the source people from communicating with target people in the language which reaches to the latter in a translated form, thereby also translating their identity as a mediated representation. In this sense, the local accessibility is also mediated through the production crew that is all Western and that is more likely to appeal to Western viewership by globalizing local cultural images.

In this way, the way the characters, language, and events are selected and organized in the movie shows that it is targeted more to the audiences abroad than to the audiences at home. It may be only because of its "big" circulation in the Hollywood that the movie is highly acclaimed and viewed in India. There are numerous other movies like Salaam Bombay (1988), Bombay (1995), Mumbai Meri Jaan (2008) produced in India before $S M$, which have dealt with harsh realities of Mumbai lives and which have hardly grabbed attention of the Western media. 


\section{Globalized market and exoticization of the local}

Globalization can be examined at different levels to see its wide-ranging impacts on various facets of peoples' lives in the world today. I will discuss the significance of globalization in the movie only in cultural level, in which, as Dissanayake (2006) observes, "the impact of consumerism, commodification, the transnationalized forms of pleasures and desires and their concomitant impact on indigenous traditions becomes extremely important" (pp. 26-27). The impact of globalization in this sense reflects on the reproduction of local cultural images that create pleasures and desires for global audiences. $S M$ reproduces a plethora of Indian traditions that arouse a pleasant viewership to global audiences. For example, the police officers' complicity with Prem Kumar, the host of the TV show, run by a dominant corporate house in India, becomes an inevitable traditional reality that faces Indian people in their everyday life and becomes a part of their social identity. However, the way the local image is represented in the movie has its pleasant and exoticizing effect upon the global audiences because they view this scene by projecting their own experiences to "other" the Third World state mechanisms as corrupt and therefore different from their own legal systems. Such transnationalized forms of pleasures and desires that local events evoke for global audiences show the direct impact of globalization in cultural level, (re)producing the local cultures for the consumption of global audiences.

The image of filth and dirt runs as a dominant image throughout the movie. Such image is mostly related to showing the rag(ish) identity of Indian slum dwellers. In one of the scenes, the child Jamal is stuck in a public toilet when he comes to know that a film celebrity is landing his hovercraft nearby the boy's settlement in order to publicize his movie. The boy is exulted to find that it is the same celebrity that he mostly reveres and also has his picture in his pocket. The child holds up the celebrity's picture with his one hand (lest the picture gets wet and damaged in the sewage drain of the toilet) and closes his nostrils with his 
other hand to avoid the stink and jumps into the sewage to come out quite filthy and stinking with his whole body dipped in the toilet drainage. He runs towards the scene, reaches to the front, and takes an autograph from the celebrity and returns home quite jubilant and proud of his "heroic" act. This scene serves as an extreme of such filth image of the slum dwellers that the movie (re)presents, offering a postcolonial lens to peep into the poverty-stricken slum life in India.

This event, like many others in the movie, may serve Western audiences as an exoticizing and romantic view of South Asia so as to see the image of the locals as the "other." Spurr (1993) talks about a colonial discourse that presents local people and their cultures as abhorrent and filthy through the images that are more likely to cater to the viewership of Western audiences. "The abhorrence of Indian life," according to Spurr, "... involves not simply a rationale for colonial domination, but also the awareness of this in-between state, where the colonial subject threatens to become neither one thing nor the other, neither civilized nor savage, but strangely without definition" (p. 84). It is exactly in similar kind of limbo that Jamal is left in the movie because he can neither belong to the West nor can be a part of the Mumbay slum life due to his strange status with the urban life achievement with slum roots. This situation leaves a negative impact in the minds of South Asian audiences because it is not only disturbing to them but also disillusioning. It is because the rise of Jamal from filth to urban life is beyond the reach of most of the people facing sheer poverty in their life. Regarding the repercussions $S M$ has left among Indian people, Seth (2009) remarks that the film is more about lasting impact, which is "about seeing Rubina [child Latika] and Ajahruddin [child Jamal] in their gowns and suits: pitch-forked from Dharavi to Los Angeles." Seth's discussion here implies that the multinational corporations' power is built on the local cultural representations that are showcased on the global stage. The two child stars, who are airlifted from the slum of Dharavi to the Kodak Theater in Los Angeles, are such local cultural representations that prevail in the minds of Western audiences 
as the "other." This example of transitional identity of local people in the globalized world shows how globalization affects the world today not only in terms of economic and political mediations but also in terms of cultural representations that are more adaptable to Western viewers than to the local because of such events' association with the former's popular belief in rags-to-riches success in the globalized world.

Boyle in $S M$ compounds the images of filth with some other exoticizing representations of Indian cultures like religion. The riots between the two hostile religious groups are presented in the movie in an exoticizing way so as to offer an "othered" picture of the Third World. Similarly, the police officers involved in the inquiry of Jamal are corrupt officials and thus are represented as symptomatic of Indian state mechanism. They connive with the producer of the show Who Wants to Be a Millionaire? in his effort to invalidate the knowledge of Jamal. The way the local practices are presented in the movie seems to imply that the Third World state mechanism are corrupt so as to invoke a sense of "other" in Western audiences. Such failure of state representatives to offer justice may be the other way of offering an exotic image of a developing country like India. Moreover, the presence of the underworld is another powerful exotic image that reinforces the picture of Third World through India as a place without law and order, whereby the people like Jamal, the child blind singer, Latika, and Salim have to suffer in the hands of the smugglers.

The film director's play with the local image of information technology by associating the protagonist with a telecommunications company, where he works to serve tea as a chai-wala, has its meaning in the movie that is suggestive of the effects of globalization in the local industry. It is while serving the telecommunications people that Jamal learns about the quiz show and nominates himself in the program. This telecommunications company works as an important cultural artifact in the context of India's thriving status in the globalized market. That Jamal becomes a part of such information 
company is equally meaningful in the movie because it delivers a message to the world that globalized international market avails everyone of opportunities to succeed in their life, irrespective of their social standing. It also manifests that telecommunications prove instrumental in advancing globalization's effects in the world. The film appeals to global audiences, who share common desires with Jamal to succeed in the world through their potential access to the world of information and knowledge.

The globalized market has given more power to the First World production companies to occupy the global cultural domain and look down upon the Third World cultures from their privileged position so that the materials selected can be more appealing to First World audiences. In this context of global distribution of power, South Asian viewers become merely the receivers of what the West-dominated media present to them. Sohat \& Stam (1996) observe the tension between these two worlds in a way to suggest that in globalized context First World becomes the exporter of Western values to non-Western societies. They point out that "the global distribution of power still tends to make the First World countries cultural 'transmitters' and to reduce most Third World countries to the status of "receivers" (p. 147).

From this discussion, it can be inferred that Indian slum people's identity dwells on the British director's perception of it as interesting, strange, or bizarre that serves the interests of Western audiences. Boyle's position here is that of an outsider looking in, the problem of which being that Boyle's subjects have no voice in this movie, and the audiences are at the mercy of his mediated representations. Boyle's subjects have their own, and most likely very different, points of view and opinions about life on a slum and what it means to be a slum dweller. In the words of Prakash (2005), "Bombay's map is a jigsaw puzzle of distinct neighborhoods marked by community, language, religion, dress, and cuisine" (p. 140), and this richness of 
Mumbai is what is missing in Boyle's mediated representation in the movie.

\section{Conclusion}

$S M$ emerges as a popular culture movie for global as well as local audiences with its reenactment of cultural images that are deeply rooted in the socio-cultural psyche of the people. The fact that a Western director has set this movie in a Third World country and selected the sources that are based more on the gaze of Western eyes than on the local people's perspective makes it speak more to Western audiences than to South Asian audiences. Moreover, the way local practices are represented in the movie as disturbing repercussions of a corrupt system in a Third World country also offers an exoticizing and romantic view of the local socio-cultural aspects to Western audiences. The strong presence of American culture throughout the movie is another such factor that contributes to Western viewership. Together, the replay of particular cultural images in the life of slum dwellers in India in a globalized context makes this movie a popular culture movie that has its significant appeal to global audiences.

\section{References}

Bachchan, A. (2009, January 13). Web log Comment. Retrieved April 20, 2009, from http://bigb.bigadda.com/?p=14457.

Boyle, D. (Director). (2008). Slumdog millionaire. Los Angeles: Warner Home Videos.

Dissanayake, W. (2006). Globalization and the experience of culture: The resilience of nationhood. In N. Gentz, and S. Kramer (Eds.), Globalization, cultural identities, and media representations (pp. 25-44). Albany, NY: State University of New York Press.

Prakash, G. (2005). Edward Said in Bombay. In H. Bhabha and W. J. T. Mitchell (Eds.), Edward Said: Continuing the 
conversation (pp. 135-141). Chicago \& London: The University of Chicago Press.

Seth, S. (2009, February 25). Brand Aid for India: Soft power comes to the fore with Danny Boyle's Oscar winner. Hindustan Times.

Shohat, E., and Stam R. (1996). From the imperial family to the transnational imaginary: Media spectatorship in the age of globalization. In Global/Local: Cultural production and the transnational imaginary (pp. 145-170). Durham \& London: Duke University Press.

Spurr, D. (1993). The rhetoric of empire: Colonial discourse in journalism, travel writing, and imperial administration. Durham \& London: Duke University Press.

Mr. Lamsal is pursuing doctoral studies at University of Louisville, USA. 